\title{
サンプル画像を用いた画像変換プロセスの自動構築
}

\author{
栘 永 慎 哉 ${ }^{\dagger}$, 正会員 長 尾 智 晴 ${ }^{\dagger}$

\section{Automatic Construction of Image Transformation Processes from Sample Images}

\author{
Shinya Masunaga ${ }^{\dagger}$ and Tomoharu $\mathrm{Nagao}^{\dagger}$
}

\begin{abstract}
This paper describes a method for automatically approximating an unknown image transformation from an original image to its target image by the use of a sequence of several known image filters, where the target image is an ideally processed image made manually. This automatic construction problem is regarded as a combinatorial optimization problem for the ordering of image filters and a genetic algorithm is employed to solve it. A population of individuals whose chromosomes represent sequences of image filters is evolved. In generation iterations, each individual is evaluated based on the difference between the target image and the image processed according to the filter sequence defined by its chromosome. This method can deal with arbitrary image transformations, and it can be applied to expert systems for image processing.
\end{abstract}

\section{1. ま え がき}

現在までにさまざまな画像処理アルゴリズムが提案 されており，それらの有効性が示されている1).しか しながら，画像処理は扱う問題に大きく依存している 場合が多く，処理対象によらずに有効な汎用的な方法 論は今のところ存在しない。このため, 実務レベルの ある特定の目的に対して画像処理を適用する際, 従来 の方法をそのまま用いるだけで充分な場合は稀であ り，従来の方法をプログラマが試行錯誤によって修正 し, 目的に合ったものに変更する必要がある。また,
医用画像からの患部の検出や印刷物の微妙な色調整な ぞ, 専門知識を持っている者や熟練者には実行できて も, その画像処理の記述が困難で一般の人には容易に 扱えない場合もある.そこで, 画像処理のカスタマイ ズあるいは画像処理の自動化・省力化を目的とした画 像処理エキスパートシステムに関する研究が行われて (る2) 5). これまでに提案されているシステムは, 特 定の画像処理フィル夕を実行して得られる画像を例示 したり，画像処理の手順やパラメータをブロック図等 を用いて視覚的にわかりやすく表示するものが多い. しかしながら,さらに省力化を図るためには，原画像

キーワード：画像変換, フィルタリング, 遺伝的アルゴリズム

1997 年 1 月 16 日, 第 2 回'97-th International Workshop on New Video Media Technology にて発表 1997 年 2 月 3 日受付

† 東京工業大学 工学部 像情報工学研究施設（广226 横浜市緑区長津田町 4259, TEL 045-924-5180)

$\dagger$ Imaging Science and Engineering Laboratory, Tokyo Institute of Technology (4259 Nagatsuta-cho, Midori-ku, Yokohama 226, Japan) 
とそれに対する処理後の画像の組(サンプル画像)を計 算機に入力するだけで，原画像に対して実行すべき画 像処理を自動構築することが望ましい.これは実例か ら処理の本質を学習する一種の逆問題6)であり一般に 非常に難解であるが, 扱う処理に制限を加えることに よってある程度可能になる場合がある。これまでに も, 画像処理の実例からその画像処理を自動構築しょ うとする試みがなされている5)。これは, あらかじめ 用意した何種類かの基本的な画像処理の組合せによ り, 処理例と同様な結果を得ようとするものである. その際, 考慮に入れる画像処理の種類の増加に伴って それらの組合せの数が膨大になるため, 経験的に得ら れた知見などを元にして適用すべき画像処理の順序な どに対して制限を与えるのが一般的である。しかしな がら, 広範囲な応用を目的にした場合, 用いる画像処 理の順序などに対して何の制限も与えない汎用的な方 法論が望まれる。そこで本論文では, 膨大な数の組合 せの中から有望な画像処理手順を効率良く探索する方 法として遺伝的アルゴリズム $(\mathrm{GA})$ を用いることによ って，扱う画像処理に対する制限を設けない方法につ いて述べる。これまでにも GA を膨張・収縮処理の 手順の最適化に適用した例が報告されて预り, その有 効性が示されている7). 本論文では, 最小值フィル 夕, 反転フィルタなど, 画像に対するより一般的なフ イルタを用いて, 特に原画像から特定の性質を持った 図形を抽出する画像変換処理を自動構築した結果につ いて述べる。

\section{2. 画像変換の自動構築法}

\section{1 本手法の原理}

本手法の概要を図 1 に示す. 本研究では, 初めに原 画像とそれに対する理想的な処理画像である目標画像 が与えられたと仮定する，このとき，原画像から目標

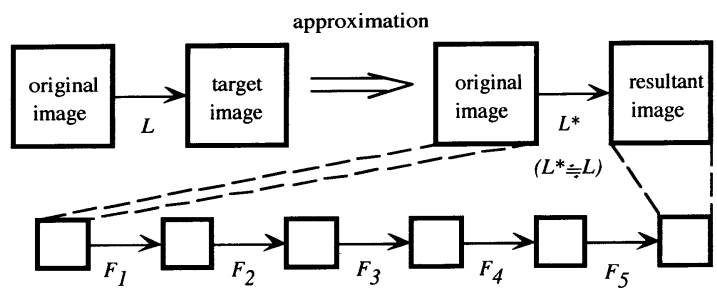

$F_{1}, F_{2}, F_{3}, F_{4}, F_{5}$ : image transformation filter

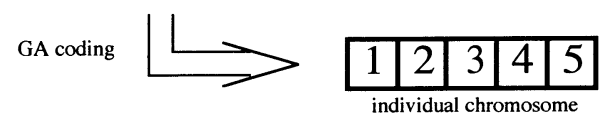

図 1 提案手法の原理

Principle of the proposed method.
画像を得るために必要な画像変換 $L$ は未知であると し, 目標画像は専門家などが経験的な知見をもとに対 話的な手段等によって手動で作成するものとする．本 手法の目的は, 未知画像変換 $L$ を, あらかじめ用意 した複数の既知の画像フィル夕を組合せることによっ

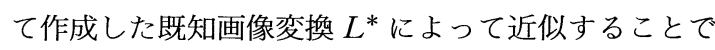
ある.ここで, 用いる画像フィルタとしては, 入力お よび出力が所定の範囲内の画素值を持つよう正規化さ れたものであれば，平滑化フィルタや微分フィルタな どの一般的なフィルタを含めて任意のフィルタを用い ることができる. 図1では, 既知画像フィル夕 $F_{1}$, $F_{2}, F_{3}, F_{4}, F_{5}$ を用いて合成された画像変換 $L^{*}=$ $F_{1} F_{2} F_{3} F_{4} F_{5}$ によって未知画像変換 $L$ を近似した例が 示されている.

近似に用いる既知画像フィルタの数の増加に伴い, それらの組合せの場合の数は膨大になる. あるフィル 夕が 1 つのフィル夕列の中に複数回現れるような画像 変換も考慮すれば，例えば 5 種のフィルタを用いただ けでも, 20 個のフィルタの並びの場合の数 $N$ は, $N$ $=5^{20}$ という膨大な数になり, 総当たり的な探索では 実用時間内に実用解を見い出すことは事実上不可能で あることがわかる．そこで本手法では，この画像フィ ルタの並びの最適化に遺伝的アルゴリズム（Genetic Algorithm; GA) 8) 11) を用いる. GA は, 最適化問題 の解を個体の染色体としてコード化し, 初期個体集団 に対して適者生存の原理に基づく淘汰・増殖をくり返 すことによって実用解を得る探索手法である。これま でに GA を画像処理 ${ }^{1213)}$ や神経回路網の設計14) に適 用した例などが多数報告され，その有効性が示されて いる. 本研究においては, 未知画像変換を近似するた めの既知画像フィルタの並びが解に相当するため, 図 1 に示したように, フィルタの識別子を並べたものを 個体の染色体とみなして GA を適用する。

\section{2 個体の染色体の定義}

2.1 節で述べたように, 用いるフィルタの識別子を 並べたものを個体 $I_{i}(i=1,2, \cdots, N)$ の染色体 $C_{i}$ とし て定義する.すなわち, 図 1 中の例である画像フィル 夕列 $F_{1} F_{2} F_{3} F_{4} F_{5}$ に対応する染色体 $C_{1}$ は次式で表さ れる。

$$
C_{1}=\{12345\}
$$

本論文では, 画像フィル夕列に含まれるフィル夕の 総数も含めてフィルタ列を最適化するものとする。す なわち個体の染色体は可変長であり, 例えば, 次に示 す $C_{2}$ や $C_{3}$ はいずれもフィル夕 $F_{1} \sim F_{5}$ を考慮に入れ た画像変換に対応する個体の染色体であるとみなす.

$$
C_{2}=\{324\}
$$




$$
C_{3}=\{445534235321123\}
$$

上記の $C_{2}$ においてフィルタ $F_{1}$ と $F_{5}$ が使用されて いないが, 個体の評価においてそのことは考慮しな い.すなわち, 本手法では“あらかじめ用意した画像 フィルタの中から重複を許して任意のフィルタを任意 の個数だけ任意の順に適用する画像変換を最適化す る”.

適用において 1 個以上の数值パラメータが必要なフ イルタについては, 一般的なパラメータの組をあらか じめ用意し，それらに対する識別子をフィルタの識別 子に付随させるものとする. 次に具体例を示す.

$$
C_{4}=\{1334 \mathrm{a} 5 \mathrm{~b}\}
$$

$4 \mathrm{a}: F_{4}$, パラメータセットa；100

$5 \mathrm{~b}: F_{5}$, パラメータセットb； $(50,150)$

本論文では, 本手法の基本的な性能を確かめること を目的としており，パラメータセットを 1 文字程度の 長さの識別子で表すことができず, パラメータの詳細 な調整が必要であるようなフィルタは今回は考慮しな いことにする。もしもこのようなフィルタを必要とす る場合は，パラメータセットの識別子に割り当てる文 字数あるいはビット数を増やし，パラメータに対する 数值最適化をフィルタ列の順序最適化と並行して行う 必要があり, 両者の探索効率を低下させないような最 適化の方法について検討する必要がある。

\section{3 個体の適応度の定義}

本研究において各個体は既知画像フィル夕列であ $\eta$, 各個体 $I_{i}(i=1,2, \cdots, N)$ の優秀さを表す值である 適応度 $f_{i}$ は, 自分自身の染色体 $C_{i}$ によって定義され る画像フィル夕列によって原画像 $\operatorname{org}(x, y)$ を変換し て得た変換後の画像 $p(x, y)$ と, 目標画像 $\operatorname{target}(x$, $y ）$ との違いを反映したものとして定義する必要があ る. 2 つ画像間の距離の定義としては, これまでに もさまざまなものが提案されているが，本論文では最 も基本的と考えられる次式によって定義される各画素 の階調值の差分の絶対値の総和を用いることにする. すなわち個体 $I_{i}$ の適応度 $f_{i}$ を次式で定義する.

$$
f_{i}=1-\frac{\sum_{x=1}^{W_{x}} \sum_{y=1}^{W_{y}}|\operatorname{target}(x, y)-p(x, y)|}{\operatorname{range} \cdot W_{x} \cdot W_{y}}
$$

ただし， $W_{x}, W_{y}$ は画像の横方向および緹方向の画素 数, rangeは画像の階調数であり, 本論文では range $=256$ である. この定義は, 画像全体を均等に 評価するものであり, 画素の持つ重要性が画像中の位 置に依存して異なるような場合には必ずしも適切な定 義とはいえないが, 今回の実験例では良好な結果を与 えた。

\section{4 淘汰・増殖規則}

GAについては，これまでに多数の改良手法が提案 されており，親から子孫への形質遺伝や個体集団中の 多様性の維持に関する改良が行われてきている15). 本 論文の目的は, 画像変換の自動化にGA を用いるこ との有効性を確認することであり，ここで扱う問題に 最も適した GA の形式を探すことではない。このた め, 本論文ではルーレットルールとエリート保存戦略 を併用する最も基本的な GA を用いた場合について 述べる。ルーレットルールとは, 次世代の個体をその 適応度に比例した生存確率で重複を許して現世代の個 体から選ぶ淘汰規則であり，エリート保存戦略とは現 世代での最良個体を必ず次世代中に残す戦略である。 これらにより, 個体集団はその平均適応度が増加する よう“進化”し, 個体集団中の最大適応度の值は世代 交代とともに単調増加する。なお, 本手法における初 期個体集団は, 一定範囲内の長さのフィルタ列をラン ダムに発生させることによって生成する.

次世代の個体を選択した後, ランダムに 2 つの個体 を選んでそれらの染色体を交叉させる処理を行う．選 んだ個体が交叉するか否かは交叉率によって決定され る. 本手法では染色体長が可変であるため, 図 2 に示 すような変形 1 点交叉法を用いた。同図において, $P_{1}, P_{2}$ が選ばれた 2 つの親個体の染色体であり， $O_{1}$, $\mathrm{O}_{2}$ がそれらの交叉によって生成された子孫の個体の 染色体の例である．各親の染色体のランダムな位置に 交叉点をそれぞれ 1 つずつ設定し，各交叉点以降の部 分フィルタ列を入れ替えることによって子孫の個体の 染色体を生成する。ここで，パラメータセットを伴う フィルタの識別子が交叉によって分断されることを避 けるため, 交叉点は常にフィルタの識別子の境界部に 設定されるという条件を付加する。この交叉によっ

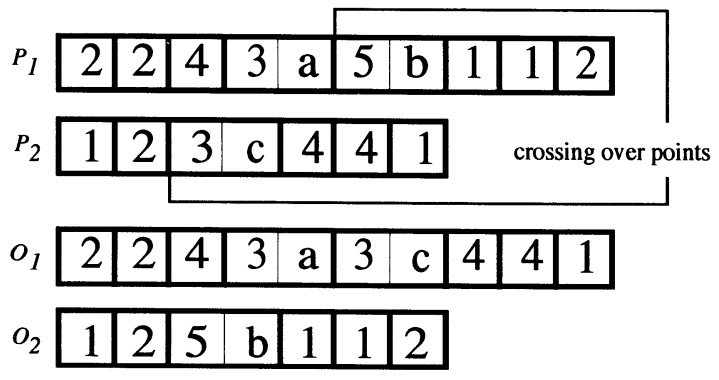

$P_{1}, P_{2}$ : parent chromosomes $O_{1}, O_{2}$ : offspring chromosomes $1,2,3,4,5:$ number of filter $\quad a, b, c:$ number of paremeter set

図 2 変形 1 点交叉 A modified one-point crossover. 


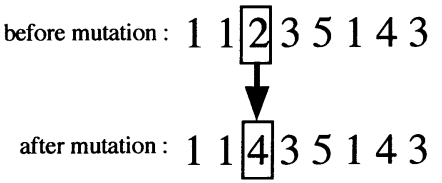

図 3 突然変異の例

An example of mutation.

て，2つの親個体の染色体から親 から受け継いだ形質が異なるさま ざまな長さの染色体を持つ子孫が 生成される。

染色体の交叉後, 各個体の各遺 伝子に対して $1 \%$ 程度の小さい生 起確率で突然変異を実行する. 本 手法では, 図 3 に例示するよう に, 染色体中のフィル夕の識別子 を, 他のフィルタの識別子にラン ダムに変更する処理である.

突然変異後の個体集団を評価 し, 終了条件を満たしていれば世 代交代を終了し，満たしていない 場合は淘汰のプロセスに戻って上 記の過程をくり返す．本手法にお いては, 個体集団中の最大適応度 が，あらかじめ決めた閾值よりも 大きくなることを終了条件とし，そのときの最大適応 度を持つ個体の染色体に対応するフィル夕列を，画像 変換の自動近似結果であるとみなす。

\section{3. 画像自動変換の実験例}

\section{1 実験結果 1}

本手法による画像自動変換の有効性を検証するため に行った実験例について述べる。ここでは，次に示す 5 つの画像フィルタを既知フィルタとして用いた。た だし, 各フィルタは画像 $f_{1}(x, y)$ から $f_{2}(x, y)$ への変 換として定義されるものとし， $T$ を閾值， $N f_{1}(x, y)$ を $f_{1}(x, y)$ の $3 \times 3$ 近傍, 原画像を $\operatorname{org}(x, y)$ とする.

(1) $F_{1}: 2$ 值化フィルタ

$$
f_{2}(x, y)=\left\{\begin{array}{rll}
255 & \text { for } & f_{1}(x, y) \geq T \\
0 & \text { for } & f_{1}(x, y)<T
\end{array}\right.
$$

(2) $F_{2}$ : 最小値フィルタ

$$
f_{2}(x, y)=\min \left\{N f_{1}(x, y)\right\}
$$

(3) $F_{3}$ : 最大値フィルタ

$$
f_{2}(x, y)=\max \left\{N f_{1}(x, y)\right\}
$$

(4) $F_{4}$ : 反転フィルタ

$$
f_{2}(x, y)=255-f_{1}(x, y)
$$

(5) $F_{5}$ : (原画像との) 差分フィルタ

$$
f_{2}(x, y)=\left|\operatorname{org}(x, y)-f_{1}(x, y)\right|
$$
ただし $F_{1}$ の 2 值化フィルタにおける閾值 $T=128$ と した。また，GAのパラメータとしては次の值を用い た. 個体集団中の個体総数 $=100$, 交叉率 $=70 \%$, 突 然変異率 $=1 \%$ ．これらはパラメー夕を決定するため の予備実験において, 平均的に良い結果を与えるパラ メータとして採用されたものである。

図 4(a) に原画像の例を示す．これは小冊子の表紙 をスキャナによって階調画像として計算機に入力した 画像であり, $256 \times 256$ 画素, 256 階調である. 図 4 (b) ) は原画像中の特定の図形だけを対話的な描画ソ フトウェアを用いて手動で切り出した画像であり,こ れを目標画像として本手法を適用した。 図 $5(\mathrm{a})$ が本 手法によって得られた画像フィル夕の適用順序列であ り, 同図 (b)がこれによって原画像を変換して得られ た画像である．若干のノイズ等の相違部分があるが, 変換後の画像は目標画像によく一致していることがわ かる. 原画像中には目標画像中の図形以外にも孤立図 


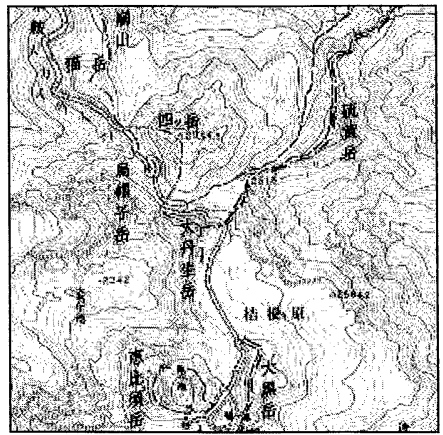

(a) 原画像 2

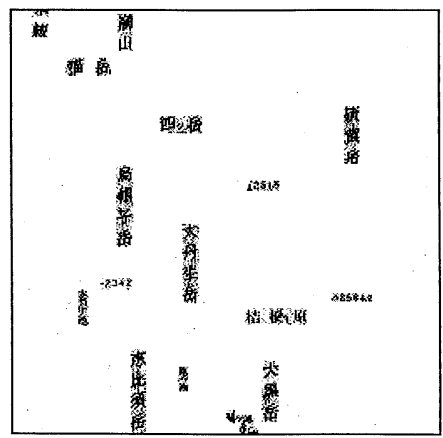

(b) 目標画像

図 6 原画像 2 とその目標画像 Original image No. 2 and its target image.

形があり，実験開始前は用意した 5 種のフィルタを用 いるだけでは原画像から目標画像への変換の近似が困 難であると予想されたが, 本手法によって近似解が与 えられたことは興味深いと考えられる。

\section{2 実験結果 2}

3.1 節で述べた実験では, 原画像から目標画像への 変換に特定の目的が存在しなかった。ここでは, 本手 法による画像変換の近似の一般性を確認するため, 画 像変換に対して特定の目的を設定した場合について述 べる. 用いたフィルタ, GA の設定は 3.1 節と同一で ある。

ここでは 2 万 5 千分の 1 地形図中の地名などの文字 列候補の自動抽出問題16) を扱う。すなわち, 原画像 として地形図を与え, その文字領域を手動で切り出し た画像を目標画像として与えることにより，地形図か ら文字領域を切り出す画像変換の構築を試みる. 図 6 (a)および (b)に原画像と目標画像をそれぞれ示す. また，本手法よって得られた画像変換およびそれを原 画像に適用した処理後の画像を図 7 ( a ) および ( b ) に それぞれ示す。この場合も目標画像の近似画像が得ら れていることがわかる。ここで得られた図 $7(\mathrm{a})$ に示

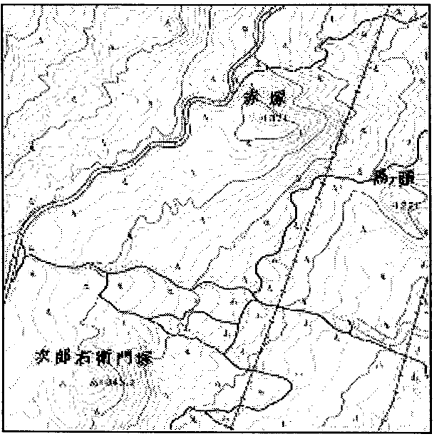

(a) 新しい画像 1

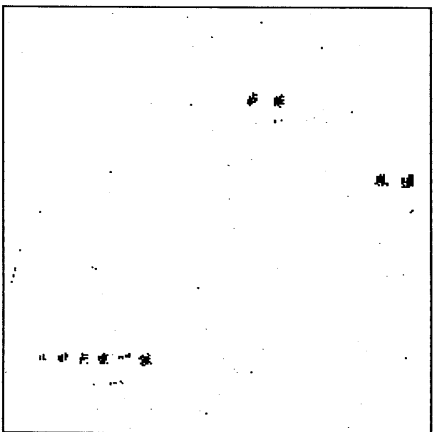

(b) 変換画像

図 8 新しい画像 1 とその変換画像 New image No. 1 and its processed image.

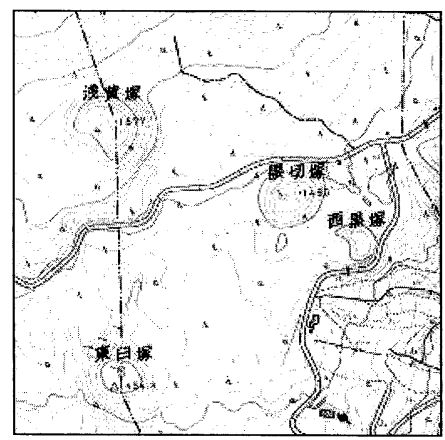

(a) 新しい画像 2

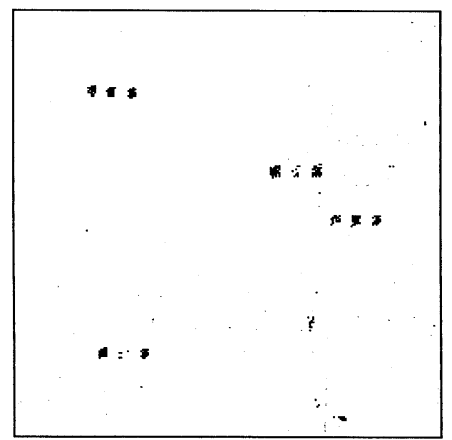

(b) 変換画像

図 9 新しい画像 2 とその変換画像 New image No. 2 and its processed image. 
す画像変換を, 新しい画像に対して適用した結果を, 図 8 と図 9 に示す。それぞれの図において(a)が原画 像, (b)が変換後の画像である.これらの結果から, 若干のノイズを含んではいるものの, 地形図からの文 字候補領域の抽出の画像変換が本手法によって比較的 良好に構築されていることがわかる。

\section{3 実験結果の考察と今後の課題}

3.1 節および 3.2 節に示した実験結果から, 原画像 とその目標画像が与えられたとき, 原画像から目標画 像への画像変換が, 本手法によって既知の画像フィル 夕の組合せとして比較的良好に近似できることがわか る. 本手法は確率的な手法であり, 同一のサンプルを 用いた場合でも，同一の実用解すなわち画像フィル夕 列が得られるとは限らない。 また, 今回は生成する画 像フィル夕列の長さを各個体の適応度評価に入れてい ないため, 得られる解が表すフィルタ列中のフィル夕 の総数も一定ではない. できるだけコンパクトな画像 変換フィル夕を生成する必要がある場合は, 同程度の 誤差の変換画像を与えるフィル夕列の中でも, 短いも のほど適応度が高いという評価を行う必要がある。

本研究で扱ったサンプル画像からの画像変換の一般 化は, 前述のように変換に関する逆問題であり, 本手 法は理論的に厳密な意味での近似法とはいえないが, 画像処理を実務に運用する場合に有効なツールである と考えることができる. 本論文では本手法の基本的な 性能評価を扱ったが, 今後さらに高度な処理内容を含 む画像変換の自動化に対して本手法を適用するために は, 近似に必要な原画像と目標画像の組の数の問題, 扱う画像フィル夕を増やした場合の処理の安定性の問 題などについて, 今後充分検討する必要がある.

\section{4. むす び}

本論文では, 任意の原画像とその理想的な処理画像 である目標画像の組が与えられたとき, 原画像から目 標画像を得るための未知の画像変換を, あらかじめ用 意した複数個の既知の画像フィルタの合成によって近 似的に求める手法について述べた。本手法では，この 画像変換の自動近似問題を既知画像フィル夕列の組合 せ最適化問題ととらえて遺伝的アルゴリズムを適用 し，本手法の有効性を実験により確認した。今後は， 本手法をさらに高度な処理内容の画像変換に適用する ために改良するとともに, 本手法の汎化能力について
も検討を行う予定である.

\section{〔参 考 文 献〕}

1）尾上守夫編 : “画像処理ハンドブック”, 昭晃堂（1986）

2）特集「画像処理エキスパートシステム」, 情報処理学会誌, 29, 2 (1988)

3）松山隆司, 尾崎正治: “LIVE：トップダウン・セグメンテー ションのための画像処理エキスパートシステム”, 情処学論, 27, 2, pp. 191-204 (1986)

4）田村秀行, 佐藤宏明, 坂上勝彦, 久保文雄: “DIA-Expert シ ステムとその知識表現方法”, 情処学論, 29, 2, pp. 199-208 (1988)

5）長谷川純一, 久保田浩明, 鳥脇純一郎：“サンプル図形提示方 式による画像処理エキスパートシステムIMPRESS”, 信学 論, J70-D, 11, pp. 2147-2153（1987）

6）小川英光: “信号と画像の復元 $[$ I ] [IV]”, 信学誌, 71，5, pp. $491-497$; 6, pp. 593-601; 7, pp. 739-748 ; 8, pp. 828-835 (1988)

7）依田育士, 山本和彦, 山田博三: “GA による構造的モルフォ ロジー手順の獲得”, 信学論, J78-D-II, 12, pp. 1758-1766 (1995)

8) J.H. Holland: "Adaptation in Natural and Artificial Systems”, the Univ. Michigan Press (1975), MIT Press (1992)

9) David E. Goldberg: "Genetic Algorithms in Search, Optimization \& Machine Learning”, Addison Wesley (1989)

10）北野宏明編：“遺伝的アルゴリズム”, 産業図書（1989）

11）安居院猛, 長尾智晴: “ジェネティックアルゴリズム”, 昭晃 堂 (1993)

12）長尾智晴, 安居院猛, 長橋宏: “遺伝的手法を用いた 2 値図形 のパターンマッチング”, 信学論, J76-D-II, 3, pp. 557-565 (1993)

13）白川英隆, 長尾智晴: “遺伝的アルゴリズムを用いた画像中 の左右対称領域の自動抽出”, テレビ誌, 50, 8, pp. 1150-1155 (1996)

14) T. Nagao, T. Agui and H. Nagahashi : "Structural Evolution of Neural Networks having Arbitrary Connections by a Genetic Method", Trans. of the IEICE, E76-D, 6, pp. 689-697 (1993)

15）小林重信: “遺伝的アルゴリズムによる探索と学習”, 日本口 ボット学会誌, 13, 1, pp. 57-62（1995）

16）長尾智晴, 安居院猛, 中嶋正之: “塊状図形分離とキーキャラ ク夕探索による 2 万 5 千分の 1 地形図からの文字列抽出”, テレビ誌, 44, 8, pp. 1044-1052(1990)

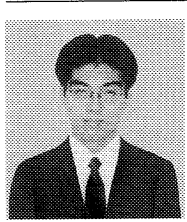

栘家永 慎哉 1996 年, 東京工業大学工学 部情報工学科卒業. 現在, 同大学大学院総合 理工学研究科知能システム科学専攻修士課程 在学中. 進化的計算法结関する研究に従事.

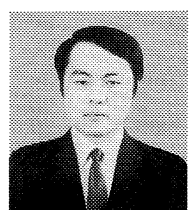

長尾 智晴 1985 年, 東京工業大学大学 院博士課程中退. 同年, 同大学助手. 1995 年, 同大学工学部像情報工学研究施設助教 授.コンピュータビジョン, 進化的計算法, 神経回路網などに関する研究に従事. 工学博 士. 正会員. 